Relative Income and Indebtedness: Evidence from Panel Data

Michael D. Carr and Arjun Jayadev

WORKING PAPER 2013-02

DEPARTMENT OF ECONOMICS

UNIVERSITY OF MASSACHUSETTS BOSTON 


\title{
Relative Income and Indebtedness: Evidence from Panel Data
}

\author{
Michael Carr and Arjun Jayadev
}

April 29, 2013

\begin{abstract}
We examine patterns of indebtedness in the Panel Study of Income Dynamics, focusing on the period surrounding the housing bubble and its aftermath (i.e. 1999-2009). Leverage increased most quickly among lower income households during this period. We find that leverage grew faster for households with lower relative income compared to other households in similar demographic groups. We also find that changes in leverage for a given household were strongly associated with lower relative income within a state, controlling for own income. A one standard deviation increase in relative income is associated with a 50 to 100 percent increase in the growth in leverage. Together, these findings provide evidence for the thesis that the rising indebtedness of households in the U.S is related to high levels of inequality, and that 'Veblen effects' whereby relative income matters for individual well-being and decisions may contribute to rising household indebtedness.
\end{abstract}




\section{Introduction}

In 1995 [Mr. Baggett] moved into a house in the Harvard-Yale section of Salt Lake, a tree-lined neighborhood near the University of Utah that is home to many doctors, lawyers and professors. Mr. Baggett used credit cards to furnish the home with the kind of carpets and furniture his neighbors and relatives could afford. "I felt insecure; I was an hourly-paid worker in this fancy neighborhood," says Mr. Baggett. He says he was making $\$ 13$ an hour for a time doing backoffice work at a local bank while supporting two children.

From 'Lagging Behind the Wealthy, Many Use Debt to Catch Up', Wall Street Journal, May 17th 2005.

In the wake of the financial crisis of 2008 and the Great Recession that followed, there has been renewed interest in private leverage, particularly in increasing levels of household indebtedness. Figure 1, drawn from the U.S Flow of Funds accounts, shows a steadily increasing ratio of household debt to GDP from the 1950s through the early 1980s. This long period of relatively slow growth in leverage was followed by an increase in the 1980s, and a much sharper increase in the post 1999 period. ${ }^{1}$. Some explanations of the reasons for the rapid leveraging up of households following 1999 include: the role of demographic changes (Barnes and Young, 2003), the impact of financial innovation in easing credit constraints (Crook and Hochguertel, 2007), changing expectations of future income, and a response to negative income shocks to smooth consumption (Iacoviello, 2008; Krueger and Perri, 2006). For a comprehensive empirical review attempting to evaluate these hypotheses see Dynan and Kohn (2009).

The aim of this paper is to provide evidence in support of another common but empirically under explored hypothesis: the idea that rising indebtedness is linked with rising inequality in the United States. Such an argument has been raised in two variants. First, rising indebt-

\footnotetext{
${ }^{1}$ The implications of this massive change in household balance sheets has been at the center of current macroeconomic debates. Much research in recent times for example has examined the importance of shocks to household balance sheets and the impact on depressed demand observed currently in the U.S. and elsewhere (Eggertson and Krugman, 2010; Guererri and Lorenzoni, 2011; Hall, 2011a,b; Mian and Sufi, 2011, 2010; Philippon and Midrigan, 2011)
} 
Figure 1: Nonfinancial Leverage, 1929-2011

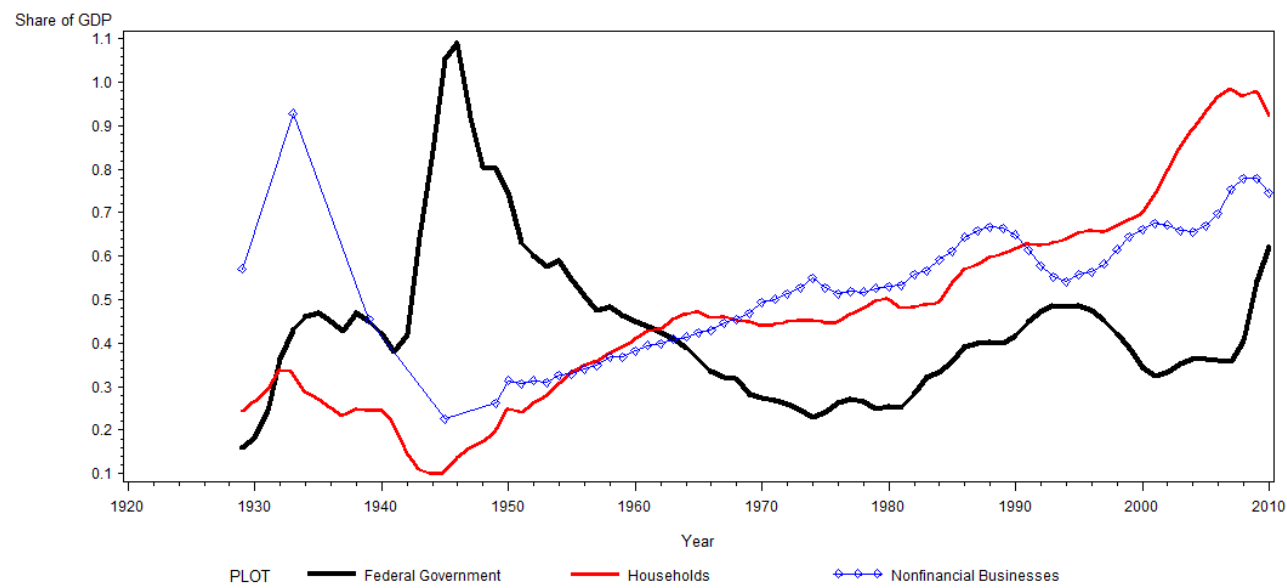

Source: Flow of Funds, Historical Statistics of the United States, A Study of Savings in the United States

edness has been seen to be at least partly the result of low income households borrowing to maintain a customary standard of living. A second variant suggests that relative stagnation - the presence of 'Veblen' effects, whereby one's own consumption is partially driven by the consumption of comparator groups - has increased indebtedness of relatively lower income households as they seek to emulate the lifestyle of richer comparator households.

The idea that rising indebtedness is caused by stagnant income growth has some prima facie plausibility considering macroeconomic patterns over the last three decades. During this period, in addition to rising household indebtedness, real wage growth was slow, personal savings rates fell, income inequality rose and productivity growth was not met by equal growth in wages. The rise in indebtedness may then be seen to be the result of households struggling to maintain a customary standard of living in the face of stagnant or falling incomes $^{2}$ Variants of this argument have been made, for example, by Rajan (2010) who

\footnotetext{
${ }^{2}$ While wages at the bottom of the distribution may be low, they have not been stagnant. Autor et al. (2006) for example suggest that wage growth has been slowest in the middle of the distribution, thereby leading to a polarization of the labor market. There is continuing debate about patterns of change for various
} 
suggests that the rise in household indebtedness is the direct result of a political response to rising inequality, where growing consumption was financed by expanding lending to households, especially low-income households. Another version of this argument is that rising inequality and lower relative income (as opposed to simply lower incomes) may be linked to increased indebtedness. It is the hypothesis that responses to lower relative income may partially explain rising levels of indebtedness that forms the bulk of our exploration.

Empirical evidence for Veblen effects have been found in several applications, as we detail in the following section. Perhaps most closely related to this paper is the work of Bertrand and Morse (2012) who find evidence for Veblen effects in consumption, where lower relative income households expenditure increases in response to the average living standards. This is in keeping with the thesis of 'Expenditure Cascades' (Levine et al., 2010), which asserts that relative income and the expenditure patterns of those higher up the income ladder influence the expenditure of households lower down.

These ideas have not been applied to household borrowing behavior during the housing boom of the 2000s. Additionally, our paper is the first, to the best of our knowledge, to use a true panel dataset (the Panel Study of Income Dynamics Wealth supplements) to explore the relationship between indebtedness and inequality. Previous efforts to examine the evolution of household indebtedness have typically utilized repeated cross-sections such as the Survey of Consumer Finances or the Consumer Expenditure Survey. The PSID allows for a more careful tracing out of the patterns of indebtedness, the timing of surges in indebtedness and its proximate correlates, and allows us to control for both time varying and invariant characteristics of households.

To foreground our findings, we show that although there is a positive link between debt growth and income growth for households on average, leverage (i.e. debt to income ratios) rose faster among lower income households than higher income households between 1999 and sections of the income distribution (Burkhauser et al., 2012; Piketty and Saez, 2003). 
2009-the period for which we have the most consistently collected data. We also find evidence that, controlling for own income, household leverage rose faster as the 'distance' between a given household and other households above it in the income distribution increased. Distance here is measured as either a) the proportion of households with higher income than a given household in a group or b) the gap in income between the highest income household in a group and the income of the household. We find that when the relative income declines, leverage for the household increased. Finally we show that these effects are strongest in states which had larger sub-prime origination. These findings are consistent with the hypothesis that inequality and Veblen effects have acted as drivers of increased leverage.

In what follows, we begin with a brief discussion of the literature on the links between inequality and indebtedness, focusing most extensively on the literature on relative income and its importance for economic decisions and well-being. In the next section, we turn to the empirical discussion with a description of the Panel Study of Income Dynamics wealth data and an examination of broad trends in the U.S. for the period 1998-2008. We then provide econometric evidence for the relative income thesis. In the preferred specification, we find that a one standard deviation increase in reference group consumption increases the growth rate of leverage by 0.02 to 0.03 percentage points over an average rate of 0.01 , controlling for own family income. The magnitude of this effect varies depending on how comparator groups are constructed but is positive, relatively large and significant across most specifications.

\section{Relative Income, Inequality and Borrowing}

A large literature has documented sharp increases in income and earnings inequality in the United States over the last three decades (Gottschalk and Danziger, 2005; Katz and Autor,

1999; Krueger and Perri, 2006; Lemieux, 2008; Piketty and Saez, 2003); contra these, see Gordon (2009)). Krueger and Perri (2006) argue that consumption inequality has not risen 
as fast as income inequality, which might be in turn interpreted to mean that debt was used to paper over rising income inequality ${ }^{3}$.

How might rising inequality affect decisions to borrow? Specifically, how can the welfare experienced by others induce behavioral changes for a given individual or household? An influential literature suggests that interpersonal comparison is a key argument in individual utility functions and thus rising inequality may be associated with behavioral changes. Positional concerns can drive individual perceptions of well-being and change economic decisions as individuals or households seek to emulate the actions of comparator groups. Research drawing from social comparison based utility functions has identified the theoretical significance (Akerlof and Kranton, 2000; Arrow and Dasgupta, 2009; Bagwell and Bernheim, 1996; Clark and Oswald, 1996; Cooper et al., 2001; Easterlin, 1974; Eaton and Eswaran, 2009; Frey and Stutzer, 2002; Layard, 1980; Van Praag, 1989; Rablen, 2008; Sen, 1983; Veblen, 1899) and empirical importance(Bowles and Park, 2005; Frank, 1989, 2008; Maurer and Meier, 2008; Neumark and Postlewaite, 1998; Oh et al., 2012) of Veblen effects .

The idea that consumption decisions in particular depend on both one's own income and that of others has a long history from at least Duesenberry (1949). Consumption preferences are driven by norms that are socially created by reference to appropriate comparator groups such as neighbors, those in the same broad social class, co-workers, models from the mass media and so on. Psychologists and behavioral economists have provided substantial support in favor of these hypotheses (see, for a review Folkes and Kiesler (1991)). Frank (2008) suggests that consumption goods act as positional externalities whereby individual households ramp up expenditure to achieve the socially created norm that evolves from the consumption of other (typically richer) households. The result is an Expenditure Cascade (Levine et al., 2010), where lower income households increase consumption following an increase in

\footnotetext{
${ }^{3}$ More recently however, there has been other evidence that consumption inequality has indeed kept pace with income inequality Attanasio et al. (2012)
} 
expenditure by higher income households. Schor (1999) suggests that media coverage and models provided in television and other mass media outlets provide comparator groups that extend beyond the one's immediate social grouping.

Cynamon and Fazzari (2008) seek to understand the rise in household borrowing as arising out of similar considerations. They provide a comprehensive discussion of the implications of growing inequality, worsening relative income and changing consumption norms for the decision to accrue debt. They suggest that the combination of rising inequality and institutional changes in the provision of credit since the 1980s have served to move households towards a new norm (as compared with social norms that prevailed in the decades before then) in which borrowing to maintain consumption has become more acceptable. Seen in this light, the standard explanation of borrowing in which the representative household borrows to smooth consumption in response to changes in prices or wealth following the life-cycle model may need to include another argument: the relative position of the household in comparison with similar groups. ${ }^{4}$.

\section{$3 \quad$ Data and Descriptive Statistics}

Our data come from the main survey and wealth supplement of the Panel Study on Income Dynamics from 1984 to 2009. The PSID is a longitudinal dataset that began with roughly 5,000 families and 18,000 individuals in 1968. The PSID follows all individuals either born to or adopted by someone in the original sample in subsequent years of the survey. The main

\footnotetext{
${ }^{4}$ The point is made elegantly by (Cynamon and Fazzari, 2008, p. 16) who write that "In a conventional life-cycle consumption model with liquidity constraints, households have a feasible, optimal plan that they would follow in the absence of constraints, but the constraint prevents current consumption from reaching this desired level. When greater access to credit relaxes the constraint, households raise debt and consumption toward the level derived from the optimal plan. These actions can be understood by looking at a representative household in isolation, without reference to broader social forces. In our context, in contrast, we view consumption and debt choices as driven to an important extent by social interaction. A family, in isolation, might choose a more conservative financial path, but the influence of neighbors, both those who have a physical presence and those whose lifestyles are piped in through the media, drives both consumption and debt higher."
} 
survey was collected yearly until 1997, where it changed to a biennial survey. The wealth survey was collected in 1984, 1989, 1994, and biannually from 1999 to the present. We use only years where the wealth survey was implemented, and focus primarily on the period in which the data is more regularly collected (i.e. after 1999).

There are three main categories of debt in the PSID: mortgage debt, vehicle debt, and other debt. We use only mortgage and other debt since data on vehicle debt is collected less frequently in the main period of interest (i.e. after 1999). The final sample used here contains 46,406 observations on 9,515 individuals. Only individuals with the PSID "gene" who are either a household head or spouse are included, resulting in each family being represented by at most one adult. We exclude individuals with missing observations for family income, remaining mortgage principal, other debt, education, number of children, and/or marital status.

Table 1 provides some descriptive statistics for the panel. The mean family income over the period in 2009 dollars was approximately $\$ 79,000$, while debt was about $\$ 66,000$. Additionally, both debt and income have very large standard deviations, reflecting the skewness of the distribution. The average debt to income ratio of 0.69 is considerably smaller than the debt to income ratio at the average of debt and income, which is 0.84 . This is indicative of both the high correlation between income and debt and the larger number of people with no recorded debt.

\section{Trends}

Before turning to more formal exploration, we provide some examination of broad trends of interest. Figure 2(a) shows the growth in both total debt and income for households between 1984 and 2009. As the first panel shows, income rose slower than debt, leading to increased

\footnotetext{
${ }^{5}$ Having the PSID "gene" means the individual is a descendant of one of the original 1968 families by either birth or adoption.
} 
Table 1: Descriptive Statistics: 1984-2009

\begin{tabular}{lrr}
\hline Variables & \multicolumn{1}{c}{ Mean } & \multicolumn{1}{c}{ Std. Dev. } \\
\hline Family income & 79160.75 & $(101481.65)$ \\
Total debt & 66151.51 & $(151699.40)$ \\
Other debt & 10409.69 & $(95406.13)$ \\
Mortgage debt & 55741.82 & $(115890.62)$ \\
Debt/Income & 0.69 & $(0.48)$ \\
Age of head & 41.72 & $(12.81)$ \\
Married & 0.64 & \\
High School or less & 0.38 & \\
Some college & 0.17 & \\
Bacherlor's & 0.14 & \\
Advanced & 0.31 & \\
Presence of children & 0.50 & \\
\hline
\end{tabular}

Notes: Authors' calculations based on PSID core family survey plus wealth supplements from 1984-2009. The baseline sample includes all individuals who (i) have the PSID "gene", and (ii) are either a household head or spouse, and (iii) are a member of a household where at least the head or spouse is employed. Family income is total money income of all family members. Total debt includes the level of all debt, both long term and short term. Mortgage debt is the principle remaining on the loan. Other debt is all debt other than mortgage debt and vehicle debt. Debt to income ratio is total family money income divided by total debt. Educational and relative income groups based on characteristics of the head of the family.

leverage. Between 1999 and 2009 average debt rose sharply from about 70,000 dollars family to over 100,000 dollars per family in 2007 (in 2009 dollars). Real income rose much more slowly following the recession of the early 2000s, and the resulting leverage in 2007 stood at over 100 percent. The results are in broad agreement with trends observed in other datasets such as the Survey of Consumer Finances and Flow of Funds which provides some measure of confidence for our subsequent empirical exploration.

In the second panel we restrict our sample to families that had positive debt throughout the period to control for the fact that debt is zero for a large number of households. As the Figure 2(b) shows, among families with positive debt average debt exceeded average income earlier than in the period roughly between 2001 and 2003. Figure 2(c) confirms the common understanding that the main driver of debt is mortgage debt, which accounts for the largest fraction of total debt. While other debt remained relatively constant, mortgage 
Figure 2: Average Family Income and Total Debt: 1984-2009

(a) Full Sample

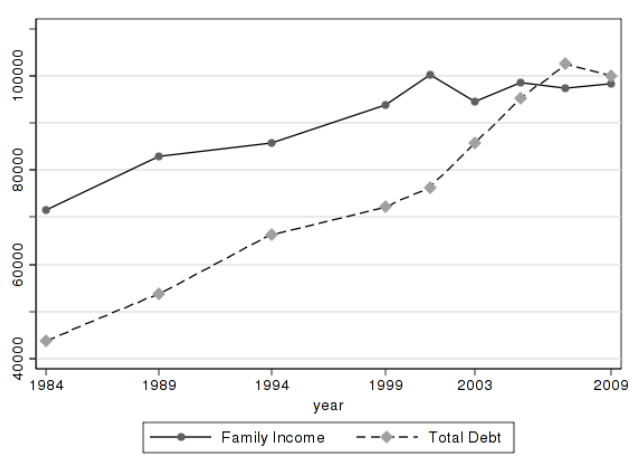

(b) Positive Debt

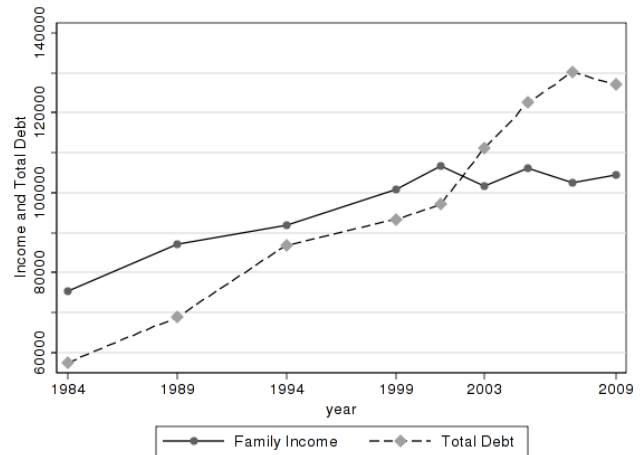

(c) Types of Debt

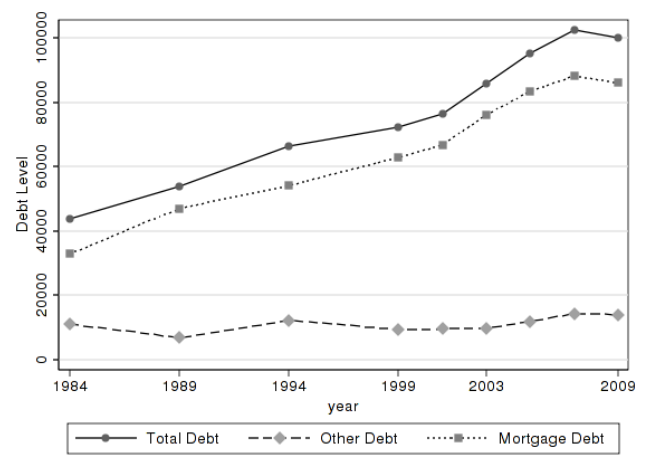

Source: Authors' calculations based on PSID core family survey plus wealth supplements from 1999 to 2009. The baseline sample includes all individuals who (i) have the PSID "gene", and (ii) are either a household head or spouse, and (iii) are a member of a household where at least the head or spouse is employed. Family income is total money income of all family members. Total debt includes the level of all debt, both long term and short term. Mortgage debt is the principle remaining on the loan. Other debt is all debt other than mortgage debt and vehicle debt.

debt increased steadily over the entire period, and at a faster rate during the 2000's.

Figure 3 depicts the differential growth of leverage across the income distribution. We split the sample into three income groups based on their level of income in 1999. The figure plots the cumulative percent change of income and debt to income ratios respectively, from 1999 to 2009. Figure 3 shows that the lowest income group had the fastest growth in leverage, totaling about 10 percentage points over the period. By contrast, the highest income group deleveraged over the period, with a cumulative reduction of about 5 percentage points.

Our purpose in depicting these trends is to provide some motivation for our estimation of 
Figure 3: Cumulative Percent Change in Debt and Debt/Income by Income Groups: 19992007

(a) Income

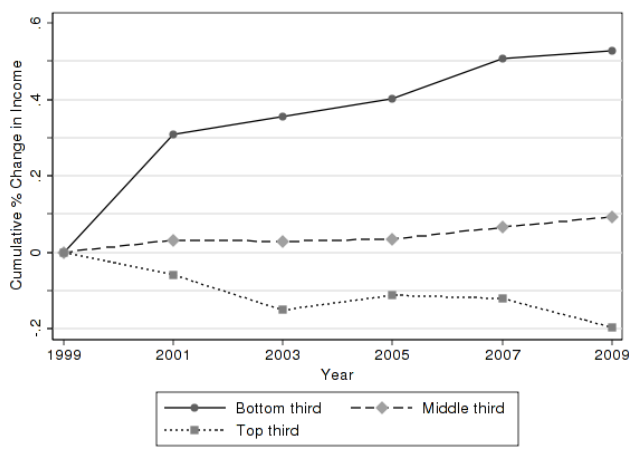

(b) Debt/Income

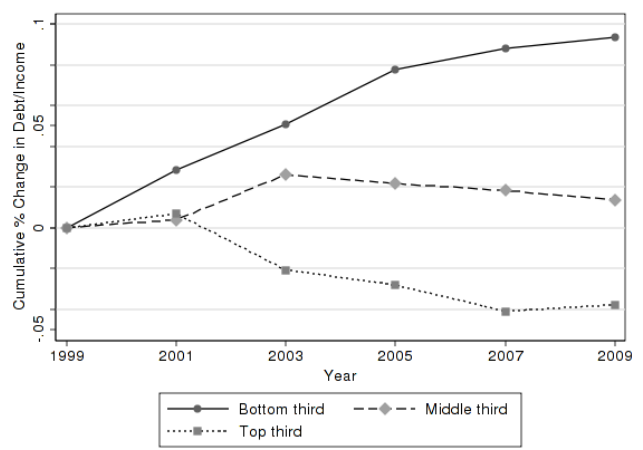

Notes: Authors' calculations based on PSID core family survey plus wealth supplements from 1999 to 2009. The baseline sample includes all individuals who (i) have the PSID "gene", and (ii) are either a household head or spouse, and (iii) are a member of a household where at least the head or spouse is employed. Family income is total money income of all family members. Total debt includes the level of all debt, both long term and short term. Debt to income ratio is the ratio of log family money income over total debt for all families with positive money income. Income groups based on total family money income in 1999 or first observed year for the paid gene individual, whichever comes first, resulting in an unbalanced sample.

Table 2: Descriptive Statistics by Income Comparison Groups

\begin{tabular}{lcccc}
\hline & Low & Middle & High & Total \\
\hline Debt/Income & 0.62 & 0.79 & 0.82 & 0.73 \\
& $(0.46)$ & $(0.39)$ & $(0.37)$ & $(0.43)$ \\
Log Family Income & 10.58 & 11.19 & 11.83 & 11.13 \\
& $(0.70)$ & $(0.49)$ & $(0.62)$ & $(0.80)$ \\
Total Debt & 6.66 & 8.85 & 9.71 & 8.22 \\
& $(5.00)$ & $(4.37)$ & $(4.32)$ & $(4.80)$ \\
Head Age & 41.88 & 45.37 & 49.80 & 45.22 \\
& $(12.05)$ & $(11.10)$ & $(10.10)$ & $(11.68)$ \\
Marital Status & 0.49 & 0.75 & 0.88 & 0.68 \\
Presence of Children & 0.53 & 0.51 & 0.44 & 0.50 \\
\hline
\end{tabular}

Notes: Authors' calculations based on PSID core family survey plus wealth supplements from 1984-2009. The baseline sample includes all individuals who (i) have the PSID "gene", and (ii) are either a household head or spouse, and (iii) are a member of a household where at least the head or spouse is employed. Family income is total money income of all family members. Total debt includes the level of all debt, both long term and short term. Debt to income ratio is log of total family money income divided by log of total debt, with debt to income ratio assigned a value of zero if total debt is zero. Income groups based on log of total family money income. 
the impact of relative income on leverage patterns. Certainly, Figure 3 also reflects life-cycle patterns in debt accumulation. Older families would typically have higher incomes in 1999 and also be paying down debt accumulated earlier in their life-cycle in the years following. Life-cycle effects also help explain declining income for the top third of households in Figure 3(a). Table 2 shows that the high income group, with an average of 50, is considerably older than the older than the middle and low income groups, with average ages of 45 and 42 , respectively. Further, both the level of income and leverage are higher in the high income group, again suggesting that the trend in leverage reflects life-cycle effects. In our formal exploration however, we control for age effects in assessing the impact of relative income on leverage ${ }^{6}$.

\section{$5 \quad$ Veblen Effects in Leverage}

A social comparison based utility function suggests that it is not simply one's own absolute position but one's position in comparision to others that also motivates behavior. One is immediately confronted here with identifying a 'relevant' comparator group. We define the relevant comparator groups to be those of the same education and race category across the country. Researchers have found compelling evidence of strong peer comparison within racial categories(Hoxby, 2000). We construct 12 household categories by combining information on the head of the household across three racial categories (white, black, and other) with four educational categories (high school, some college, college, and advanced). We also interact the racial and educational categories, respectively, with the individual's state of residence.

\footnotetext{
${ }^{6}$ We do not depict an age-adjusted figure in this section since removing the effect of the lifecycle in this context is less than straightforward. Using the standard methods of estimating permanent income, and an analogous concept for debt, would remove precisely the short-term trend that we are trying to capture. Using some measure of residual income and debt presents problems for calculating changes, as the residual from a regression of income on age will result in both negative and positive residual values of income. Finally, using the coefficients on year dummies of a regression of income on age also will not work because we need a time trend within each income group, not across the entire sample.
} 
This combination of place and demographic based groups is frequently used in the existing literature on both happiness and inequality(Carr, 2013; Clark et al., 2008a; Luttmer, 2005) and the Veblen effects literature(Charles et al., 2009)

Since the largest component of debt is mortgage debt and this has varied across states, we also use geographical proximity as an additional category. One might like to use census tracts or similarly disaggregated geographical groupings to assess relative consumption patterns. However, the publicly available PSID only provides data at the state level, and hence we use families living in the same state as the primary comparison group.

There are many possible measures of relative income Clark et al. (2008b). The behavioral economics literature suggests that social comparisons are localized in time and space; and that comparisons are typically made with reference to those above an individual in the income parade rather than the whole distribution or those below. We assume accordingly that individuals respond to the standard of living of those above them in the income distribution and for an indicator of relative income $\left(Z_{i t}\right)$ that possesses this property, we utilize two indicators developed in Brown et al. (2008): the proportion of households with income greater than for household $i,\left(P G_{i g t}\right)$ and the income gap between $i$ and the maximum income in the group $\left(I G_{i g t}\right)$.

These are defined as:

$$
P G_{i g t}=\frac{N_{g t}-\sum I\left[I=1 \mid i n c_{-i g t}>i n c_{i g t}\right]}{N_{g t}}
$$

and

$$
I G_{i g t}=\frac{\max \left(i n c_{g t}\right)-i n c_{i g t}}{\max \left(i n c_{g t}-\min \left(i n c_{g t}\right)\right.}
$$

respectively

where $I \in\{0,1\}$ is an indicator variable indicating whether a given individual's family 
income is greater than individual $i$ 's family income, $i$ indexes individuals, $t$ indexes time, and $g$ indexes group. The measures of relative income are bounded between 0 and 1 by construction. Descriptive statistics for the relative income measures are provided in Table 3. The means of the proportion greater $(\mathrm{PG}$ ) variables are roughly 0.50 (as they should be given they are head count variables). The means of the income gap variables are less than 0.50 reflecting the right skewed nature of the income distribution.

Table 3: Descriptive Statistics of Relative Income Measures

\begin{tabular}{lcrr}
\hline Variables & Symbol & Mean & Std. Dev. \\
\hline State income gap & $\mathrm{IG}_{S}$ & 0.39 & $(0.19)$ \\
State prop. greater & $\mathrm{PG}_{S}$ & 0.50 & $(0.29)$ \\
State/Race income gap & $\mathrm{IG}_{S / R}$ & 0.41 & $(0.22)$ \\
State/Race prop. greater & $\mathrm{PG}_{S / R}$ & 0.49 & $(0.29)$ \\
State/Educ income gap & $\mathrm{IG}_{S / E}$ & 0.43 & $(0.29)$ \\
State/Educ prop. greater & $\mathrm{PG}_{S / E}$ & 0.46 & $(0.29)$ \\
Educ/Race income gap & $\mathrm{IG}_{E / R}$ & 0.35 & $(0.16)$ \\
Educ/Race prop. greater & $\mathrm{PG}_{E / R}$ & 0.50 & $(0.29)$ \\
\hline
\end{tabular}

Source: Authors' calculations based on PSID core family survey plus wealth supplements from 1999 to 2009. The baseline sample includes all individuals who (i) have the PSID "gene", and (ii) are either a household head or spouse, and (iii) are a member of a household where at least the head or spouse is employed. Family income is total money income of all family members measures in thousands. Measures calculated using the $\log$ of total family income. Race has three categories: white, black, and other. Educational attainment is based on highest degree earned of head, and has four categories: high school or less, some college, Bachelor's degree, and advanced degree.

\subsection{Regression Results}

Our key regression is :

$$
\Delta\left(\frac{D}{Y}\right)_{i t}=\alpha+Y_{i t}+Z_{i t}+\mathbf{X}_{i t}+\delta_{t}+\gamma_{i}+u_{i t}
$$

The dependent variable of interest $\Delta\left(\frac{D}{Y}\right)_{i t}$ is the change in the debt to income ratio, measured as the the ratio of log (total debt) to log (total family money income) . Family income $\left(Y_{i t}\right)$ is measured in thousands and $\mathbf{X}$ refers to a vector of controls. The main independent 
variable i, $Z_{i t}$, refers to the indicator of relative well being (based on the distribution of log family income). ${ }^{7}$.

The results of the regressions are shown in Table 4 . Columns 1 and 2 show that conditioned on own income, leverage grows faster for those whose income is lower relative to those who are of the same race by education groups, defined nationally. The largest effect of any group coming from Educ/Race groups, where a one standard deviation increase in the proportion of the group who has higher income than a given individual is associated with an increase in the growth rate of leverage of 0.029 on an average rate of 0.011 . The results show that, for a given level of income, an increase in either $P G$ or $I G$ increases the growth in Debt/Income for all comparison groups.

In Columns 3 and 4 , and 5 and 6 , we repeat the exercise, this time replacing the comparator groups with state by race groups, and state by education groups, respectively. Once again, the relative position of the individual household, conditional on the households' income is a statistically significant correlate of growth in leverage. The coefficients on the state by race groups are comparable to the coefficients on the state groups, but the coefficient on $\mathrm{PG}_{S / E}$ is considerably smaller than the comparable coefficient for the entire state.

In column 7 we consider Veblen effects within the state, with all residents of the state being a comparator group. Leverage increases as the proportion of income earners in the state of residence with a higher income than the household increases, and as the income gap increases. A one standard deviation increase in $P G_{S}$ is associated with a 0.047 unit increase in growth of the debt to income ratio. Given that the average change is 0.015 units, this is a relatively large effect. A one standard deviation increase in $I G_{S}$ is associated with a 0.032 unit increase in the growth of the debt to income ratio. All of the estimated effects, regardless of reference group, are roughly in this range.

\footnotetext{
${ }^{7}$ Using logs in the dependent and levels in the independent helps break collinearity between family income and the relative income measures, which are based on logs rather than levels
} 


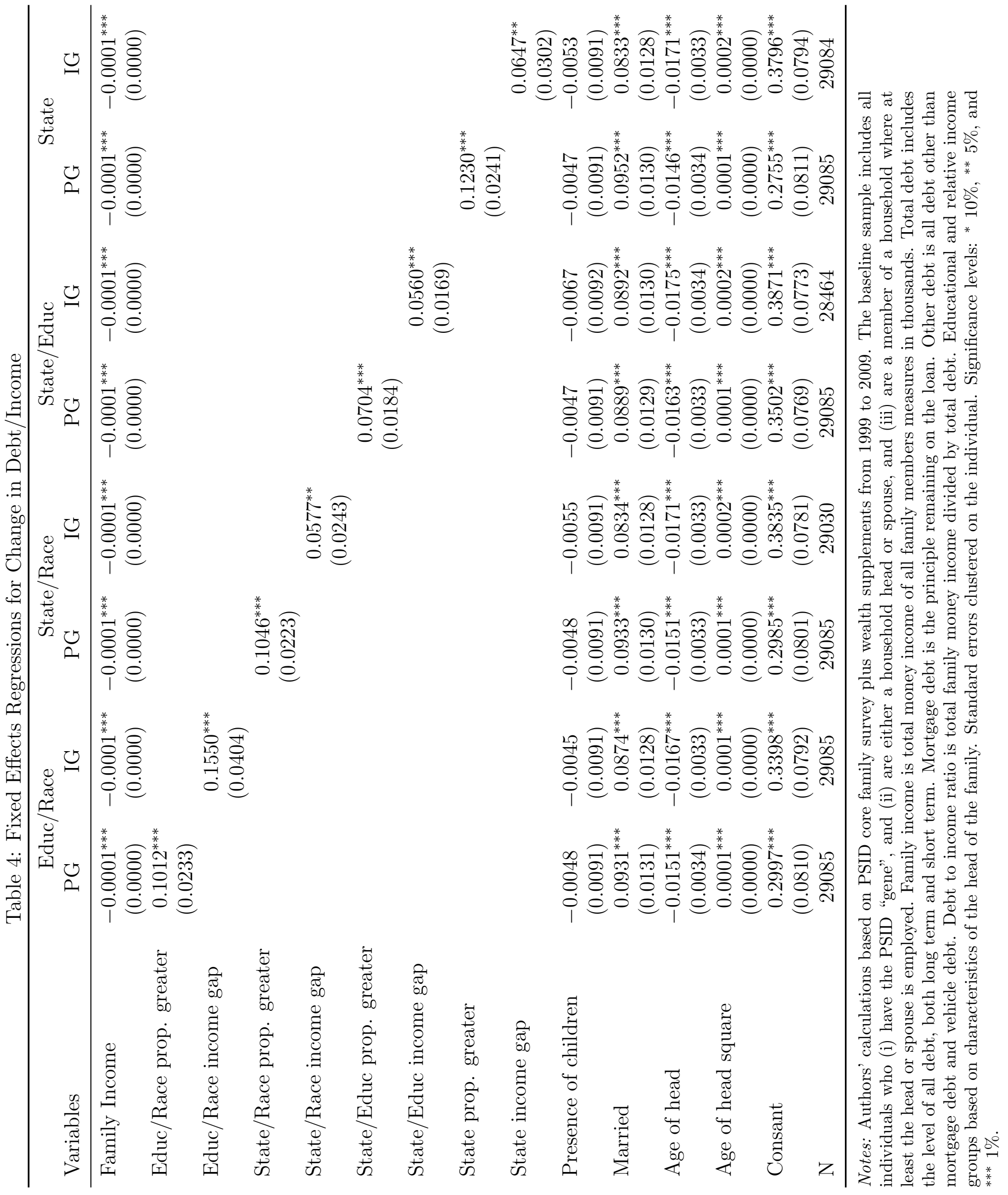


The effects are largest for Education $\mathrm{x}$ Race, suggesting that comparison with similar demographic characteristics drives consumption more strongly than comparison with others within the state.

Given that the largest part of debt is mortgage debt and that the period under consideration saw differential patterns in the growth of lending (Mayer and Pence, 2008), we examine differences across states in the rise of leverage, this time dividing the states into those with above median subprime originations and those with below median subprime origination in 2005. Table 5 provides descriptive statistics for the two groups. In general the characteristics are very similar, although total debt and income was slightly higher on average in high subprime states than in low subprime states.

Table 6 runs our main regression on the two samples separately. A sharp difference is immediately evident. While leverage is positively correlated with relative income (albeit insignificantly with the income gap variable), the coefficient is much larger in high subprime states than in low subprime states. This provides some support for the idea that as flexibility in lending rules increased, relatively poorer households used this to increase their consumption to match consumption among higher income households. ${ }^{8}$

\section{Conclusion}

In this paper we ask whether the rise in household indebtedness in the U.S in the last decade is linked to growing income inequality. More specifically, we address the following questions using the Panel Study of Income Dynamics. First, are low income households more likely to leverage up than higher income households? And second, is leverage higher when the

\footnotetext{
${ }^{8}$ Another potential explanation is that relative income is purely a proxy for credit constraints and that looser standards simply allowed lower income families to increase consumption to desired levels while such constraints did not limit higher income families. However, we condition on the family's own income, and such an interpretation would mean that lenders discriminate on relative rather than absolute income - an interpretation that seems difficult to support.
} 
Table 5: Descriptive Statistics by Subprime Lending Rate: 1999-2009

\begin{tabular}{|c|c|c|c|}
\hline Variables & Low Subprime & High Subprime & Difference \\
\hline Family income & 82937.695 & 85138.451 & $\begin{array}{r}-2200.756^{*} \\
{[1258.243]}\end{array}$ \\
\hline Total debt & 76450.985 & 77425.079 & $\begin{array}{l}-974.094 \\
{[1386.003]}\end{array}$ \\
\hline Other debt & 11007.820 & 10509.793 & $\begin{array}{c}498.026 \\
{[657.187]}\end{array}$ \\
\hline Mortgage debt & 65443.165 & 66915.286 & $\begin{array}{c}-1472.121 \\
{[1195.928]}\end{array}$ \\
\hline Debt/Income & 0.724 & 0.704 & $\begin{array}{c}0.020^{* * *} \\
{[0.005]}\end{array}$ \\
\hline Age of head & 42.640 & 42.273 & $\begin{array}{l}0.367^{* *} \\
{[0.143]}\end{array}$ \\
\hline Married & 0.634 & 0.609 & $\begin{array}{l}0.025^{* * *} \\
{[0.005]}\end{array}$ \\
\hline High school or less & 0.342 & 0.370 & $\begin{array}{c}-0.028^{* * *} \\
{[0.005]}\end{array}$ \\
\hline Some College & 0.194 & 0.181 & $\begin{array}{l}0.013^{* * *} \\
{[0.004]}\end{array}$ \\
\hline Bachelor's & 0.154 & 0.149 & $\begin{array}{l}0.005 \\
{[0.004]}\end{array}$ \\
\hline Advanced & 0.310 & 0.300 & $\begin{array}{l}0.010^{* *} \\
{[0.005]}\end{array}$ \\
\hline Presence of children & 0.459 & 0.502 & $\begin{array}{c}-0.043^{* * *} \\
{[0.006]}\end{array}$ \\
\hline $\mathrm{IG}_{S}$ & 0.431 & 0.427 & $\begin{array}{c}0.004^{* *} \\
{[0.002]}\end{array}$ \\
\hline $\mathrm{PG}_{S}$ & 0.493 & 0.497 & $\begin{array}{c}-0.004 \\
{[0.003]}\end{array}$ \\
\hline
\end{tabular}

Notes: Authors' calculations based on PSID core family survey plus wealth supplements from 1999 to 2009. The baseline sample includes all individuals who (i) have the PSID "gene", and (ii) are either a household head or spouse, and (iii) are a member of a household where at least the head or spouse is employed. Family income is total money income of all family members. Debt to income ratio is total family money income divided by total debt. Educational and relative income groups based on characteristics of the head of the family. High Subprime states have an above median share of subprime originations in 2005. Significance levels: ${ }^{*} 10 \%,{ }^{* *} 5 \%$, and ${ }^{* * *} 1 \%$. 
Table 6: Fixed Effects Regressions for Change in Debt/Income by Amount of Subprime Lending in State

\begin{tabular}{|c|c|c|c|c|}
\hline & \multicolumn{2}{|c|}{ Low Subprime State } & \multicolumn{2}{|c|}{ High Subprime State } \\
\hline & $\mathrm{PG}$ & IG & $\mathrm{PG}$ & IG \\
\hline Family income & $\begin{array}{c}-0.0002^{* *} \\
(0.0001)\end{array}$ & $\begin{array}{c}-0.0002^{* * *} \\
(0.0001)\end{array}$ & $\begin{array}{c}-0.0000^{* *} \\
(0.0000)\end{array}$ & $\begin{array}{c}-0.0001^{* * *} \\
(0.0000)\end{array}$ \\
\hline State prop. greater & $\begin{array}{c}0.0603^{*} \\
(0.0334)\end{array}$ & & $\begin{array}{l}0.1645^{* * *} \\
(0.0371)\end{array}$ & \\
\hline State income gap & & $\begin{array}{c}0.0482 \\
(0.0385)\end{array}$ & & $\begin{array}{c}0.0781 \\
(0.0481)\end{array}$ \\
\hline Presence of children & $\begin{array}{c}-0.0068 \\
(0.0135)\end{array}$ & $\begin{array}{c}-0.0064 \\
(0.0135)\end{array}$ & $\begin{array}{c}-0.0004 \\
(0.0125)\end{array}$ & $\begin{array}{c}-0.0025 \\
(0.0125)\end{array}$ \\
\hline Married & $\begin{array}{l}0.0614^{* * *} \\
(0.0198)\end{array}$ & $\begin{array}{l}0.0567^{* * *} \\
(0.0193)\end{array}$ & $\begin{array}{l}0.1130^{* * *} \\
(0.0179)\end{array}$ & $\begin{array}{l}0.0973^{* * *} \\
(0.0175)\end{array}$ \\
\hline Age & $\begin{array}{c}-0.0164^{* * *} \\
(0.0047)\end{array}$ & $\begin{array}{c}-0.0171^{* * *} \\
(0.0048)\end{array}$ & $\begin{array}{c}-0.0132^{\text {*** }} \\
(0.0049)\end{array}$ & $\begin{array}{c}-0.0171^{* * *} \\
(0.0048)\end{array}$ \\
\hline $\mathrm{Age}^{2}$ & $\begin{array}{l}0.0001^{* * *} \\
(0.0000)\end{array}$ & $\begin{array}{l}0.0001^{* * *} \\
(0.0000)\end{array}$ & $\begin{array}{l}0.0001^{* *} \\
(0.0001)\end{array}$ & $\begin{array}{l}0.0002^{* * *} \\
(0.0001)\end{array}$ \\
\hline Constant & $\begin{array}{l}0.3912^{* * *} \\
(0.1123)\end{array}$ & $\begin{array}{l}0.4188^{* * *} \\
(0.1128)\end{array}$ & $\begin{array}{c}0.2087^{*} \\
(0.1199)\end{array}$ & $\begin{array}{l}0.3668^{* * *} \\
(0.1144)\end{array}$ \\
\hline $\mathrm{N}$ & 12737 & 12737 & 16348 & 16347 \\
\hline
\end{tabular}

Notes: Based on authors' calculations of PSID data for 1999 to 2009. The sample includes all individuals who (i) have the PSID "gene", and (ii) are either a household head or spouse, and (iii) are a member of a household where at least the head or spouse is employed. Family income is total money income of all family members. Debt to income ratio is total family money income divided by total debt. Educational and relative income groups based on characteristics of the head of the family. High Subprime states have an above median share of subprime originations in 2005. State of residence determined by last observed state for a given individual. Standard errors are clustered on the individual. Significance levels: ${ }^{*} 10 \%,{ }^{* *} 5 \%$, and ${ }^{* * *} 1 \%$.

relative income of a household is lower? Using various specifications, we find compelling evidence in support of both hypotheses. There exist of course additional hypotheses that we do not concern ourselves with in this paper-for example, changing expectations of permanent income.

Recent research in behavioral economics provides substantial reason to have some confidence in the notion that relative income and consumption are key drivers of behavior. Our finding here adds to the literature. Given the centrality of household indebtedness for 
macroeconomic and other policy, our findings provide new insights. Relative income and social comparison may also be core determinant of critical macroeconomic patterns. To the extent this is true, rising inequality is an issue not simply of social and political concern, but a concern for policy makers in considering issues of indebtedness and macroeconomic fragility. 


\section{References}

Akerlof, George A. and Rachel E. Kranton, "Economics And Identity," The Quarterly Journal of Economics, August 2000, 115 (3), 715-753.

Arrow, Kenneth J. and Partha S. Dasgupta, "Conspicuous Consumption, Inconspicuous Leisure*," The Economic Journal, 2009, 119 (541), F497-F516.

Attanasio, Orazio, Erik Hurst, and Luigi Pistaferri, "The Evolution of Income, Consumption, and Leisure Inequality in The US, 1980-2010," Working Paper 17982, National Bureau of Economic Research April 2012.

Autor, David H., Lawrence F. Katz, and Melissa S. Kearney, "The Polarization of the U.S. Labor Market," American Economic Review, May 2006, 96 (2), 189-194.

Bagwell, Laurie Simon and B Douglas Bernheim, "Veblen Effects in a Theory of Conspicuous Consumption," American Economic Review, June 1996, 86 (3), 349-73.

Barnes, Sebastian and Garry Young, "The rise in US household debt: assessing its causes and sustainability," Bank of England working papers 206, Bank of England November 2003.

Bertrand, Marianne and Adrian Morse, "Trickle Down Consumption," Technical Report 2012 .

Bowles, Samuel and Yongjin Park, "Emulation, Inequality, and Work Hours: Was Thorsten Veblen Right?," Economic Journal, November 2005, 115 (507), F397-F412.

Brown, Gordon D. A., J Gardner, Andrew J. Oswald, and Jing Qian, "Does Wage Rank Affect Employees' Well-being?," Industrial Relations: A Journal of Economy and Society, 2008, $47(3), 355-389$. 
Burkhauser, Richard V., Jeff Larrimore, and Kosali I. Simon, "A "Second Opinion" on the Economic Health of the MIddle Class," National Tax Journal, 2012, 65 (1), 7-32.

Carr, Michael D., "Local Area Inequality and Worker Well-Being," Review of Social Economy, 2013, 71 (1), 44-64.

Charles, Kerwin Kofi, Erik Hurst, and Nikolai Roussanov, "Conspicuous Consumption and Race," The Quarterly Journal of Economics, 2009, 124 (2), 425-467.

Clark, Andrew E. and Andrew J. Oswald, "Satisfaction and comparison income," Journal of Public Economics, September 1996, 61 (3), 359-381.

_, Paul Frijters, and Michael A. Shields, "Relative Income, Happiness, and Utility: An Explanation for the Easterlin Paradox and Other Puzzles," Journal of Economic Literature, 2008, 46 (1), 95-144.

${ }_{-},{ }_{-}$, and _ , "Relative Income, Happiness, and Utility: An Explanation for the Easterlin Paradox and Other Puzzles," Journal of Economic Literature, March 2008, 46 (1), 95-144.

Cooper, Ben, Cecilia Garcia-Penalosa, and Peter Funk, "Status Effects and Negative Utility Growth," The Economic Journal, 2001, 111 (473), 642-665.

Crook, Jonathan and Stefan Hochguertel, "US and European Household Debt and Credit Constraints," Tinbergen Institute Discussion Papers 07-087/3, Tinbergen Institute November 2007.

Cynamon, Barry Z. and Steven M. Fazzari, "Household Debt in the Consumer Age: Source of Growth,Risk of Collapse," Capitalism and Society, 2008, 3 (2), 3.

Duesenberry, J.S., Income, Saving, and the Theory of Consumer Behavior Harvard economic Studies, Harvard University Press, 1949. 
Dynan, Karen E. and Donald L. Kohn, "The rise in U.S. household indebtedness: causes and consequences," Finance and Economics Discussion Series 2007-37, Board of Governors of the Federal Reserve System (U.S.) 2009.

Easterlin, Richard A., "Does economic growth improve the human lot? Some empirical evidence," Nations and households in economic growth, 1974, 89.

Eaton, B. Curtis and Mukesh Eswaran, "Well-being and Affluence in the Presence of a Veblen Good*," The Economic Journal, 2009, 119 (539), 1088-1104.

Eggertson, Gauti B and Paul Krugman, "Debt, Deleveraging, and the Liquidity Trap: A Fisher-Minsky-Koo approach," Federal Reserve Bank Working Paper November 2010.

Folkes, Valerie and Thomas Kiesler, "Social Cognition: Consumers' Inferences about the Self and Others," in Thomas S. Robertson and Harold H. Kassarjian, eds., Handbook of Consumer Behavior, Vol. 3 of Handbook of Consumer Behavior, Prentice Hall, 1991, pp. 281-315.

Frank, Robert H, "Frames of Reference and the Quality of Life," American Economic Review, May 1989, 79 (2), 80-85.

Frank, Robert H., "Should public policy respond to positional externalities?," Journal of Public Economics, August 2008, 92 (8-9), 1777-1786.

Frey, Bruno S. and Alois Stutzer, Happiness and economics, Princeton, NJ [u.a.]: Princeton Univ. Press, 2002.

Gordon, Robert J., "Misperceptions About the Magnitude and Timing of Changes in American Income Inequality," Working Paper 15351, National Bureau of Economic Research September 2009. 
Gottschalk, Peter and Sheldon Danziger, "Inequality of Wage Rates, Earnings and Family Income in the United States, 1975-2002," Review of Income and Wealth, 06 2005, $51(2), 231-254$.

Guererri, Veronica and Guido Lorenzoni, "Credit Crises, Precautionary Savings and the Liquidity Trap," Working Paper, University of Chicago Booth School 2011.

Hall, Robert E., "The High Sensitivity of Economic Activity to Financial Frictions*," The Economic Journal, 2011, 121 (552), 351-378.

_ , "The Long Slump," American Economic Review, 2011, 101 (2), 431-69.

Hoxby, Caroline, "Peer Effects in the Classroom: Learning from Gender and Race Variation," Working Paper 7867, National Bureau of Economic Research August 2000.

Iacoviello, Matteo, "Household Debt and Income Inequality, 1963-2003," Journal of Money, Credit and Banking, 08 2008, 40 (5), 929-965.

Katz, Lawrence F. and David H. Autor, "Changes in the wage structure and earnings inequality," in O. Ashenfelter and D. Card, eds., Handbook of Labor Economics, Vol. 3 of Handbook of Labor Economics, Elsevier, October 1999, chapter 26, pp. 1463-1555.

Krueger, Dirk and Fabrizio Perri, "Does Income Inequality Lead to Consumption Inequality? Evidence and Theory," The Review of Economic Studies, 2006, 73 (1), 163-193.

Layard, Richard, "Human Satisfactions and Public Policy," Economic Journal, December 1980, 90 (363), 737-50.

Lemieux, Thomas, "The changing nature of wage inequality," Journal of Population Economics, January 2008, 21 (1), 21-48. 
Levine, Adam, Robert Frank, and Oege Van Dijk, "Expenditure Cascades," Working Paper, Social Science Research Network February 2010.

Luttmer, Erzo F. P, "Neighbors as Negatives: Relative Earnings and Well-Being," Quarterly Journal of Economics, August 2005, 120 (3), 963-1002.

Maurer, Jürgen and André Meier, "Smooth it Like the 'Joneses'? Estimating PeerGroup Effects in Intertemporal Consumption Choice," The Economic Journal, 2008, 118 (527), 454-476.

Mayer, Christopher J. and Karen Pence, "Subprime Mortgages: What, Where, and to Whom?," Working Paper 14083, National Bureau of Economic Research June 2008.

Mian, Atif and Amir Sufi, "House Prices, Home Equity-Based Borrowing, and the US Household Leverage Crisis," American Economic Review, August 2011, 101 (5), 2132-56.

Mian, Atif R. and Amir Sufi, "Household Leverage and the Recession of 2007 to 2009," NBER Working Papers 15896, National Bureau of Economic Research, Inc April 2010.

Neumark, David and Andrew Postlewaite, "Relative income concerns and the rise in married women's employment," Journal of Public Economics, October 1998, 70 (1), $157-183$.

Oh, Seung-Yun, Yongjin Park, and Samuel Bowles, "Veblen effects, political representation, and the reduction in working time over the 20th century," Journal of Economic Behavior and Organization, 2012, 83 (2), 218-242.

Philippon, Thomas and Virgiliu Midrigan, "Household Leverage and the Recession," Working Paper 16965, National Bureau of Economic Research April 2011.

Piketty, Thomas and Emmanuel Saez, "Income Inequality In The United States, 19131998," The Quarterly Journal of Economics, February 2003, 118 (1), 1-39. 
Praag, B.M.S. Van, "The Relativity of the Welfare Concept," Research Paper 69, World Institute for Development Economics Research 1989.

Rablen, Matthew D., "Relativity, Rank and the Utility of Income*," The Economic Journal, 2008, 118 (528), 801-821.

Rajan, Raghuram, Fault Lines: How Hidden Fractures Still Threaten the World Economy, W.W Norton and Company, 2010.

Schor, Juliet B., The Overspent American: Why We Want What We Don't Need, Harper Paperbacks, May 1999.

Sen, Amartya, "Poor, Relatively Speaking," Oxford Economic Papers, July 1983, 35 (2), $153-69$.

Veblen, T., The Theory of the Leisure Class, Amereon Ltd, 1899. 


\section{A Appendix}

The income and debt information is self-reported, resulting in a small number of individuals with inconsistent responses. Individuals who report having other debt, but do not provide a value of the debt, are excluded. Any individual who reports not having other debt is assigned a debt of zero and included in the analysis. A similar procedure is used with remaining mortgage principal. If an individual reports having a mortgage, but does not report a value, the individual is excluded. Any individual who reports not having a mortgage is assigned a value of zero, this group consists almost exclusively of renters and individuals who own their residence outright. Note that both categories of debt are calculated at the household level, so even if the individual's name is not e.g. on the mortgage and thus does not officially own the debt, the debt is assigned to the individual.] 